\title{
EFFECT OF GROSS DOMESTIC PRODUCT, INFLATION, INTEREST RATE, PROFITABILITY AND CAPITAL ADEQUACY RATIO TO NON PERFORMING LOAN ON MIXED BANKS IN 2012-2015
}

\author{
Ekayana Nurnaningtyas \\ Fakultas Ekonomi, Universitas Negeri Surabaya \\ e-mail: ekayananurnaningtyas@gmail.com \\ Purwohandoko \\ Fakultas Ekonomi, Universitas Negeri Surabaya \\ e-mail: puwohandoko@unesa.ac.id
}

\begin{abstract}
Bank is a financial institution with the purpose of providing loans and services. Credit is the provision of money or product that is equated with money to make an agreement between the bank and the borrower where the borrower is obliged to fulfill its obligations within the period specified by the interest paid first. But in the process of lending to the public, the banks have problems such as credit risk, where the borrower is unable to repay the loan as agreed. So this raises the problem loans or bad credit. This study aims to determine the effect of economic factors, which uses variable Gross Domestic Product (GDP), inflation, and interest rates, as well as the internal bank uses variable profitability by proxy Return on Assets (ROA), and the Capital Adequacy Ratio (CAR) against nonperforming loans (NPLs). Data used in this study is taken from mixed banks year period 2012-2015. The analytical method used in this study is the linear multiple regression analysis. Variabel interest in this study is removed from the model because it does not pass the classic assumptions test. The research results are variable GDP negative effect on NPLs, the economy will increase the value of NPLs. CAR negative effect on NPLs, increasing the bank's capital will reduce the level of NPLs. ROA and inflation does not affect the NPL, any changes in these two variables do not affect the value of the NPL.
\end{abstract}

Keywords: non-performing loans, gross domestic product, inflation, return on assets, capital adequacy ratio

\section{INTRODUCTION}

Bank is a financial institution whose function is to raise funds from the surplus fund and distributed to those in need of funds. Funds from the bank to the public in the form of loans, ie loans that must be repaid along with interest according to agreement agreed. Every form of credit, the bank has a risk of inefficient repayment, bad credit, and the risk of default. The risk will affect the health and survival of a bank, or called by the NPL. In this study the factors that affect the NPL are seen from the macro-economic factors and internal bank. Judging from the macroeconomic factors that influence the NPL is GDP, inflation, and interest rates. In terms of internal bank, factors that affect the profitability and NPL CAR.

The first variable that affects the NPL is GDP. According to Keynes, the main factors that determine the level of a country's economy is the aggregate expenditure, spending on public goods and services. Economic conditions that indicate a stable consumption is also stable. Economy is stable, indicating that the level of income increases, the rate of bank loans also increased. So that the NPL ratio declined. Assibey and Asenso (2015) showed that GDP had a negative effect on the NPL. Where GDP higher the value of NPLs decreased. The results are supported by research conducted by Greenidge and Grossvenor (2010) who also stated that GDP negative effect on NPLs. Washington (2014) also said that GDP negative effect on NPLs. However, the different result shown by Skarica (2013) which states that the GDP had a positive effect on the NPL. When GDP increases, the value of NPLs is also increasing. As well as the results of other studies that suggest that GDP is not having an effect on the NPL. 
Inflation is also an important variable to study. Inflation is the rise in prices in the economy. Inflation causes decreased purchasing power and impact on the decline in sales. The sales decline will lead to companies having difficulties in paying the loan installments and interest on loans. So the impact is increasing NPLs. Research shows that the inflation rate has a positive effect on the NPL (Skarica, 2013). Where if inflation increases, the value of NPL also rose. The results are supported by Greenidge and Grossvenor (2010) who said that the inflation rate has a positive effect on the NPL. However, the results indicated by different Washington (2014) which states that the rate of inflation a significant negative effect on the NPL. If inflation increases, the value of NPLs will decline. And the results of this study are supported by Akinlo and Emmanuel (2014) which states that the rate of inflation a significant negative effect on the NPL.

Results of research on the influence of interest rates on the NPL is still diverse. Interest rate is the price of money expressed in percent per unit of time. When interest rates rise, will lead to the ability of the debtor to pay the credit off. This will have an impact on the level of NPLs of banks decreased. Research shows interest rates have a positive impact on the NPL (Washington, 2014). If interest rates rise, the borrower will find it difficult to pay the loan because of the possibility of borrowers will remain while their spending will increase. So that they will have trouble paying credit can caused NPL banks will increase. This study was supported by research conducted Messai and Jouin (2013) who also said that interest rates have a positive impact on the NPL. However, the results indicated by different Sabaet al (2013) say that interest rates have a negative impact on the NPL. Where if interest rates rise, the value of NPLs will decline. As well as other studies have shown that the rate does not affect the NPL (Sever and Hepsen, 2013).

Other variables that influence the NPL ratio is profitability. Wherein the variable use this proxy Return on Assets (ROA). Return on Assets (ROA) ratio is selected as deemed appropriate to measure the effectiveness of managers in the company's assets to obtain income. Increasing ROA shows the advantage achieved by the bank also increased, the less likely the bank in trouble. So it can be said that the higher the ratio of NPL NPL ratio decreased. Research conducted by Messai and Jouin (2013) revealed that the ROA has a negative effect on the NPL. However, the results indicated by different Makriet al (2014) who said that ROA has a negative effect on NPLs. While the research conducted by Boudriga et al (2009) revealed that the ROA does not affect the NPL.

The fifth variable that affects the NPL is CAR. CAR is the ratio that indicates how much of the total assets of the bank are risky part financed from its own capital in addition to receiving funding from sources outside the bank. Increased levels of a bank's CAR, indicating that the bank's capital increase. Increased capital will cover credit risk that occurs in the bank. Covered with the credit risk of the credit quality also improved. It will reduce the bank's NPL ratio. Research shows that there is a positive effect CAR to the NPL (Server and Hepsen, 2013). However, these results contradict research conducted by Boudrigaet al (2009) which states that the CAR has a negative effect on the NPL.

According Hariyani (2010: 52), the NPL ratio was describing the ability of management to manage a bank loan. The increasing NPL ratio makes the credit quality of banks worse and resulted in the increasing number of problem loans, thus increasing the possibility of major banks in the troubled state. According to Bank Indonesia Circular Letter No. 17/19 / DPUM July 8, 2015 is the sum of NPL loans or financing substandard, doubtful, and loss. The following is the movement of the average percentage of NPLs of the banks listed in the Financial Services Authority (FSA) by year 2012 to 2015 .

Figure 1 shows a graph of the percentage of NPLs of banks in 2012-2015. It can be seen that the bank is likely to continue to increase between years 2012-2015 are mixed bank. NPL ratio of banks mixture since 2012 to 2015 increased from $0.63 \%, 0.66 \%, 1.08 \%$ and $1.55 \%$. While other banks tend to fluctuate. A phenomenon that occurs in the bank to attract a mix of research for the movement of the percentage of NPLs in the bank with a mixture of different banks. So the author makes bank as a mixture of objects. 


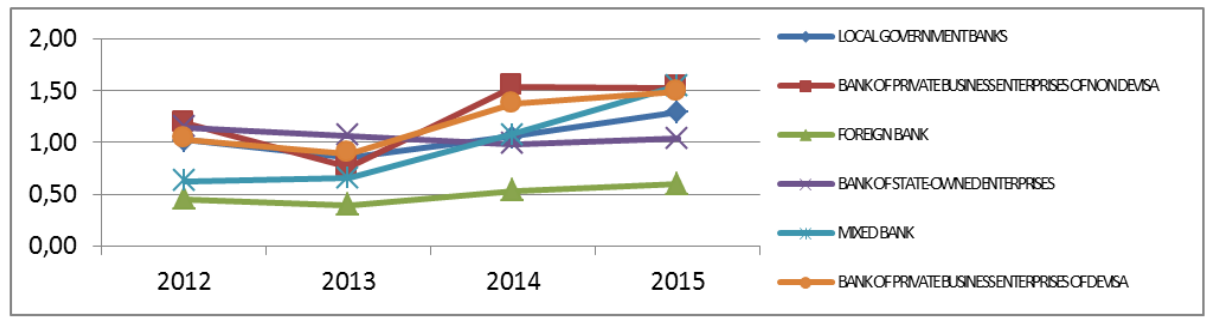

Figure 1

Percentage NPL ratio of banks in 2012- 2015

Source: Financial Services Authority

\section{Literature Review and Hypothesis}

Keynesian theory Keynesian economics is a theory proposed by John Maynard Keynes, a British economist of the 20th century this theory suggests a mixed economy, in which both the private sector and the government plays an important role. Keynesian macroeconomics reveals that can affect the behavior of individual microeconomics. Keynes says that government policy can be used to increase demand (Sukirno, 2012: 7). Keynesian theory emphasizes that the most important factors that determine the level of the state economy is the aggregate expenditure. Economic decisions affecting the behavior of the economy for the long term that will affect macroeconomic variables and other short-term fluctuations which affect the consumption of economic fluctuations (Sukirno, 2012:7).

\section{Bank Liquidity Theory}

Hasibuan (2005:98), explains the theories developed by the liquidity of the banking practitioners, among others:

\section{a. The commercial loan theory}

This theory states that a bank will remain in the liquid state when the loans are short term loans and can be availed in the normal course of business. If the bank wants to give long-term loans, the funds should be obtained from the bank's capital and long-term funding sources.

\section{b. The theory shiftability}

This theory assumes that the liquidity of a bank depends on the ability of a bank to transfer its assets to another person at a price that can be predicted. If a bank has assets that can be transferred or sold quickly, the bank said in a liquid state.

\section{c. The anticipated income theory}

This theory assumes that the level of health is fine if bank can loan repayment plan back to the income earned in the future. Based on this theory, credit should be given long-term loan, the repayment of which is expected to be scheduled in accordance with the time frame has been set.

$\mathrm{d}$. The gentleman agreement theory

Based on this theory, banks can make cooperation with fellow members of the clearing bank by interbank call money market of banks that lend to banks that borrow to maintain minimum liquidity. This cooperation needs to be done so that no bank or a clearing member suspended. If there is a bank that received a suspension, resulting in a decrease in the level of trust to the bank, so the possibility of saving the rush drawing large.

e. The liability management theory

Based on this theory to maintain minimum liquidity of banks can be done in a way that has a network of loan is quite a lot. Both of colleagues and of call money. That is how the bank is able to manage its debt so that the debt can be used as a source of funds for liquidity.

\section{Empirical Studies}

Research shows that the GDP had a negative effect on NPLs (Greednidge and Grosvenor, 2010), in which real GDP growth to increase the ability of the borrower to repay the debt they contribute to the NPL ratio was lower. The research was supported by research and Messai Jouin (2013), which also revealed that GDP had a negative effect on the NPL. This study shows that the increase in GDP will lead to increased household income. So the ability to pay credit increase and the level of NPLs will decline.

$H_{1}$ : Gross Domestic Product has a negative effect on NPL

Research shows that inflation has a positive effect on the NPL (Skarica, 2013). High inflation will have an impact on the ability of borrowers to repay loans. Same thing with research conducted by Greenidge and Grosvenor (2010) who also stated that inflation has a positive effect on the NPL. High rates of inflation would be to create a 
climate of economic uncertainty and it leads to increased levels of nonperforming loans.

$\mathrm{H}_{2}$ : Inflation has a positive effect on $\mathrm{NPL}$

Previous studies related to the effect of interest rates on the NPL also stated that the interest rate on prominent positive coverage. As a study conducted by the Washington (2014), with rising interest rates, borrowers will find it difficult to pay the loan, because the possibility of their income remains. And Messai and Jouin (2013). Higher interest rates would lead to an increase in non-performing loans, especially for loans with floating interest rates. This relationship can be explained by a decrease in the ability of borrowers to meet their obligations.

$\mathrm{H}_{3}$ : Interest rates have a positive impact on the $N P L$

According Hariyani (2010: 53) ROA is the ratio that reflects the bank's ability to earn an income after tax obtained from the asset. The higher the ROA, the more benefits the bank also increased the possibility that the small banks in the troubled state. So it can be said with rising NPLs and the NPL ratio down. Research conducted by Messai and Jouin (2013) says that the ROA has a negative effect on NPLs. Bank with a strong level of profitability that is making banks earn larger and can avoid the risk of bad debts.

$\mathrm{H}_{4}$ : Return on assets has a negative effect on $\mathrm{NPL}$

CAR declining value due to total capital decreased or increased the value of risk-weighted assets. Capital with a small amount due to declining revenues. The decrease in revenues is due to the increase in NPLs in the bank. Research conducted by Boudriga et al (2009) states that the CAR has a negative effect on NPLs. This indicates that capital serves as an indicator of financial exposure of the overall banking arrangements. This study suggests that the CAR can be used as a device to reduce the risk of bank credit.

$\mathrm{H}_{5}$ : Capital Adequacy Ratio has a negative influence on the NPL

\section{METHODOLOGY}

\section{Type of Research}

This type of research in this study is using a quantitative research. This study uses the classical assumption of normality test, multicollinearity, autocorrelation, heteroscedasticity, and linearity, multiple linear regression, hypothesis testing and the test statistic $\mathrm{F}, \mathrm{t}$ test statistics, and determination R2.

\section{Source of Data}

The secondary data sources for this study were obtained from the official website of the Otoritas Jasa Keuangan (OJK), Bank Indonesia (BI), the Central Statistics Agency (BPS), and mixed banks listed in the OJK. This study using purposive sampling as a sampling technique. Where the criteria used are banks that reported on the financial statements of the OJK in 2012-2015 and mixedbanks listed on the FSA that its NPL ratio has a value above $0 \%$. The following criteria are proposed to take the sample in this study:

Table 1

Criteria for Sampling

\begin{tabular}{|c|l|c|}
\hline No & \multicolumn{1}{|c|}{ Criteria } & Number \\
\hline 1 & $\begin{array}{l}\text { Mixed Bank listed in the OJK } \\
\text { for the period 2012-2015 }\end{array}$ & 24 \\
\hline 2 & $\begin{array}{l}\text { Bank mixtures financial reports } \\
\text { on OJK }\end{array}$ & $(11)$ \\
\hline 3 & $\begin{array}{l}\text { Bank NPL ratio of the mixture } \\
\text { is 0\% }\end{array}$ & (2) \\
\hline \multicolumn{2}{|c|}{ Total sample } & 11 \\
\hline
\end{tabular}

\section{Variable Description}

Variables that will be examined in this study using measurements as follows:

Table 2

Table of Variables

\begin{tabular}{|c|l|l|}
\hline No & Variable & \multicolumn{1}{|c|}{ Measurement } \\
\hline 1 & NPL & $\frac{\text { Total Nonperf orming Loan }}{\text { Total Credit }}$ X100\% \\
\hline 2 & GDP & GDP growth rate per year (\%) \\
\hline 3 & Inflation & $\begin{array}{l}\text { The inflation rate based on the } \\
\text { annual CPI (\%) }\end{array}$ \\
\hline 4 & $\begin{array}{l}\text { Interest } \\
\text { rate }\end{array}$ & $\begin{array}{l}\text { Bank Indonesia interest rate (BI } \\
\text { rate) per year }(\%)\end{array}$ \\
\hline 5 & ROA & ROA $=\frac{E A T}{\text { TotalAsset }}$ X100\% \\
\hline 6 & CAR & CAR $=\frac{\text { Capital }}{\text { ATMR }}$ X100\% \\
\hline
\end{tabular}

\section{Model Specification}

Models of regression in this study was to examine the effect of the independent variable (X) is the Gross Domestic Product (GDP), inflation (NFL), interest rate (SBI), Return on Assets (ROA), and the Capital Adequacy Ratio (CAR ) against non-performing loan (NPL). Where the model will be tested as follows: 


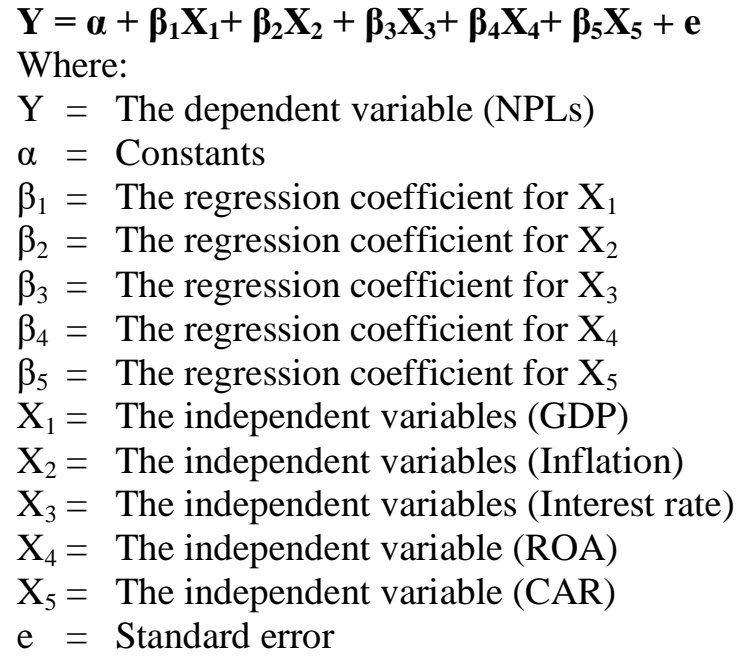

\section{Data Analysis and Results}

The first analysis performed in this study is the classical assumption. This test is done in order to get a model that is BLUE (Best Linear Unbiased Estimator). This test was conducted to determine the deviation in the data used. Based on the results of the calculations, the variables used in this study includes Non Performing Loan (NPL), Gross Domestic Product (GDP), inflation, return on assets (ROA), and the Capital Adequacy Ratio
(CAR). In the calculation of this variable interest rate removed from the model. This is done because the variable interest rates do not qualify for the classical assumption that multicolinierity.

One sample test results show that the magnitude of KS value is 0,518 with significant value 0,951 and greater than 0,05 . These results show that the data are normally distributed. The test results show multicoliniearity variance Inflation Factor (VIF) under 10 as well as the value of tolerance is 0,1 . This model suggests that there is no multicollinearity. Auotokolerasi test results show the value of DW is 2,229 , the number of $\mathrm{N}=$ 40 and $5 \%$ degree of confidence we can get the value du is 1,7209 . Then du $<$ DW $<4-d u=1,7209$ $<2,229<2,279$, so there is no autocorrelation. Heteroskedastisitas test results show that the significance of each variable on the confidence level of 0,05 or $5 \%$. So it can be said that the model is not heterokedasitis symptoms. Linearity test results show the value of count $\mathrm{c} 2(0,024)<\mathrm{c} 2$ table $(55,75484)$, it can be said that the model is already on the linear model.

Table 3

Results of Test Classical Assumptions

\begin{tabular}{|c|c|c|c|}
\hline No & Test & Result & Decision \\
\hline \multirow[t]{2}{*}{1} & $\begin{array}{l}\text { Normality (Kolmogorov- } \\
\text { Smirnov test) }\end{array}$ & test statistic $=0,518$ & Normally Distributed \\
\hline & & asymp. Sig (2-tailed) = 0,951 & \\
\hline \multirow[t]{4}{*}{2} & Multicoliniearity & GDP: Tolerance $=0.724 \mathrm{VIF}=1,380$ & No multicoliniearity \\
\hline & & Inflation: Tolerance $=0,912 . \mathrm{VIF}=1,096$ & \\
\hline & & ROA: Tolerance $=0,841$. VIF $=1,189$ & \\
\hline & & CAR: Tolerance $=0,784$. VIF $=1,275$ & \\
\hline \multirow[t]{3}{*}{3} & $\begin{array}{l}\text { Autocorrelation (Durbin- } \\
\text { Watson) }\end{array}$ & DW value $=2,229$ & No autocorrelation \\
\hline & & $\mathrm{N}=40, \mathrm{~K}=4(\mathrm{du}=1,7209)$ & \\
\hline & & du $<$ DW $<4-d u=1,7209<2,229<2,279$ & \\
\hline \multirow[t]{4}{*}{4} & Heteroskedasticity & GDP: Sig. $=0,718$ & No heteroskedasticity \\
\hline & & Inflation: Sig. $=0,249$ & \\
\hline & & ROA: Sig. $=0,073$ & \\
\hline & & CAR: Sig. $=0,906$ & \\
\hline \multirow[t]{3}{*}{5} & Linearity & c2 count: $\mathrm{R} 2=\mathrm{N} \times 40 \times 0,006=0,024$ & Linear \\
\hline & & $\mathrm{c} 2$ table $(\mathrm{df}=40,5 \%$ sig $)=55,75848$ & \\
\hline & & c2 count $<\mathrm{c} 2$ table & \\
\hline
\end{tabular}

Source: SPSS output

\section{Test of Hypothesis}

Based on the results of the $t$ test, showed that GDP and CAR have a negative effect on NPLs, while the inflation rate and ROA does not affect the NPL. 
Table 4 shows the results of testing hypothesis of each independent variable on the dependent variable. Here are the results of the hypothesis:

- Test result, the influence of the GDP NPL showed a coefficient of $-3,300$ with significance $0,002<0,05$. The $\mathrm{H}_{1}$ accepted.

- Test result, the effect of inflation on the NPL showed a coefficient of $-0,927$ with a significance level of $0,36>0,05$. The $\mathrm{H}_{2}$ is rejected.

- Test result, the influence of the NPL ROA shows coefficient $-1,211$ with significant value $0,234>$ 0,05 . The $\mathrm{H}_{3}$ is rejected.

- Test result, the influence of the CAR NPL showed a coefficient of $-2,150$ with a significance value of $0,039<0,05$. The $\mathrm{H}_{5}$ accepted.
Table 4 obtained by multiple linear regression equation as follows: $\mathrm{NPL}=6,255-0,731$ GDP - 0,046 CAR + e

It means if there is an increase of 1 point, there will be a decrease in GDP of 0,731 points and a decrease of CAR of 0,046 points.

Table 4 shows the value of R2 is 0,269 or $26.9 \%$. It means the ability to model the variation in the dependent variable explained $26.9 \%$. While the remaining $73.1 \%$ is influenced by other variables outside the model.

Table 4

Results of t-test

\begin{tabular}{llcccll}
\hline \multirow{2}{*}{ Model } & \multicolumn{2}{c}{$\begin{array}{c}\text { Coefficients } \\
\text { unstandardized }\end{array}$} & & T & Sig. & Decision \\
\cline { 2 - 5 } & B & $\begin{array}{c}\text { Std. } \\
\text { error }\end{array}$ & & & \\
\hline 1 & (Constant) & 6,255 & 1,440 & 4,345 & 0,0005 & \\
\cline { 2 - 5 } GDP & $-0,731$ & 0,222 & $-3,300$ & 0,002 & $\begin{array}{l}\text { Significant } \\
\text { negative }\end{array}$ \\
\hline Inflation & $-0,037$ & 0,039 & -.927 & 0,360 & Not significant \\
\hline ROA & $-0,100$ & 0,083 & $-1,211$ & 0,234 & Not significant \\
\hline CAR & $-0,046$ & 0,021 & $-2,150$ & 0,039 & $\begin{array}{l}\text { Significant } \\
\text { negative }\end{array}$ \\
\hline
\end{tabular}

Source: SPSS output

Table 5

Result of F-test

\begin{tabular}{lclc}
\hline \multicolumn{1}{c}{ Model } & F & Sig. & Decision \\
\hline $\begin{array}{l}\text { Regression } \\
\text { residual } \\
\text { total }\end{array}$ & 4,589 & 0,004 & Significant \\
\hline
\end{tabular}

Source: SPSS output

Table 6

Result of Adjusted R2

\begin{tabular}{cc}
\hline Model & Adjusted R Square \\
\hline 1 & 0,269 \\
\hline
\end{tabular}

Source: SPSS output

Table 4 shows the results of testing hypothesis of each independent variable on the dependent variable. Here are the results of the hypothesis:

- Test result, the influence of the GDP NPL showed a coefficient of $-3,300$ with significance $0,002<$ 0,05 . The $\mathrm{H}_{1}$ accepted.
- Test result, the effect of inflation on the NPL showed a coefficient of $-0,927$ with a significance level of $0,36>0,05$. The $\mathrm{H}_{2}$ is rejected.

- Test result, the influence of the NPL ROA shows coefficient -1,211 with significant value 0,234 > 0,05 . The $\mathrm{H} 3$ is rejected.Test result, the influence of the CAR NPL showed a coefficient of $-2,150$ with a significance value of $0,039<0,05$. The $\mathrm{H}_{5}$ accepted.

Table 4 obtained by multiple linear regression equation as follows: $\mathrm{NPL}=6,255-0,731$ GDP - 0,046 CAR +e

It means if there is an increase of 1 point, there will be a decrease in GDP of 0,731 points and a decrease of CAR of 0,046 points. Table 6 shows the value of $\mathrm{R} 2$ is 0,269 or $26.9 \%$. It means the ability to model the variation in the dependent variable explained $26.9 \%$. While the remaining $73.1 \%$ is influenced by other variables outside the model. 


\section{DISCUSSION}

Based on the results of hypothesis testing showed that GDP significant negative effect on NPLs. Negative relationship will explain that the increase in GDP will decrease the level of NPLs of the bank. Countries with high levels of GDP shows the economy is growing. This was followed by rising incomes. In line with the increase in revenues, the ability to repay the loan also increased. NPLs of banks that will be dropped. The results have a negative effect on research supported by research conducted by GDP had a negative effect on NPLs which increased GDP growth per capita will lead to a decrease in the credit risk of banks because it will improve the economic condition of companies and households so they can pay off the amount loans because their economy is improved. Research by Greednidge and Based on the results of testing the hypothesis that inflation is not known to have an effect on NPLs. Inflation today will have no effect on the NPL today. Because it takes a long time to influence the bank's NPL and will have an impact on future periods (Rahmadani, 2015 in Rosita and Musdholifah, 2016).

Based on the results of hypothesis testing showed that the profitability of the proxy ROA does not affect the bank's NPL. These results are not in accordance with the anticipated income theory. This theory assumes that the level of bank health is good if the bank is able to plan its debt back with the revenue generated in the future. Results are not influenced by this line of research conducted by Boudriga et al (2009), which explained that the banking system is likely to hide the variation of the poor performance of individual banks, so a low level of NPLs.

Based on the results of testing the hypothesis that known CAR negative effect on NPLs. This is in accordance with the Commercial Loan Theory, which holds that a bank will remain in the liquid state when the loans are short term loans and can be availed in the normal course of business. If the bank wants to give long-term loans, the funds should be obtained from the bank's capital and long-term funding sources. Results showed that CAR negative effect on NPLs is in line with research conducted by Diansyah (2016) and Boudriga et al (2009) which explains that capital serves as an indicator of the risk of financial and banking suggest that the CAR can be used as an indicator of a bank to take risks.

\section{Conclusion}

Results showed that Gross Domestic Product (GDP) has a negative effect on NPLs. Countries with high levels of GDP shows the economy is growing. This was followed by rising incomes. In line with the increase in revenues, the ability to repay the loan also increased. So NPL bank will decline. Inflation does not affect the NPL. Significance of these results is the rise and fall of inflation does not affect the bank's NPL ratio. Because changes in the inflation rate will not be felt at that moment, but will have an effect on subsequent years. Return on Assets (ROA) does not affect the NPL. That change did not affect the ratio of ROA NPL ratio of banks. Because the banking system is likely to hide the variation of the poor performance of individual banks, so a low level of NPLs. Capital Adequacy Ratio (CAR) have a negative effect on the NPL. The significance of these results is increasing the value of the CAR and decreasing NPL. The high value of the CAR show greater ability of banks to minimize credit risk with capital owned.

\section{REFERENCE}

Ahmad, Fawad. 2013. "Corruption and Information Sharing as Determinants of Non-Performing Loans". Business System Research. Vol. 4(1): pp 87-89

Ahmad, Fawad dan Bashir, Taqadus. 2013. "Explanatory power of Bank Specific Variables as Determinants of NonPerforming Loans: Evidence form Pakistan Banking Sector". World Applied Sciences Journal vol. 22(9): pp 12201231

Akinlo, Olayinka dan Emmanuel, Mofoluwaso. 2014. "Determinants of Non-Performing Loans in Nigeria". Accounting \& Taxation. Vol. 6(2): pp 21-28

Ali, Masyhud. 2004. Asset Liability Management: Menyiasati Risiko Pasar dan Risiko Operasional dalam Perbankan. Jakarta: Elex Media Komputindo.

Arikunto, Suharsimi. 2006. Prosedur Penelitian: Suatu Pendekatan Praktis Edisi 6. Jakarta: PT. Rineka Cipta

Arthesa, Ade. 2006. Bank dan Lembaga Keuangan Bukan Bank. Jakarta: Indeks

Boediono. 1992. Seri Sinopsis Pengantar Ilmu Ekonomi. Yogyakarta: BPFE

Boudriga, Abdelkader, Neila Boulila Taktak, and Sana Jellouli. 2009. "Banking 
Supervision and Non Performing Loans: a Cross-Country Analysis". Journal of Financial Economic Policy. Vol. 1(4): pp 286-318

Budisantoso, Totok dan Triandaru, Sigit. 2006. Bank dan Lembaga Keuangan Lain. Jakarta: Salemba Empat.

Clichici, Dorina dan Colesnicova, Tatiana. 2014. "The Impact of Macroeconomic Factors on Non-Performing Loans in The Republic of Moldova”. National Institute for Economic Research.pp 73-78

Diansyah. 2016. "Pengaruh Faktor Internal Dan EksternalTerhadap Non Performing Loan (Studi Pada Bank yangTerdaftar di Bursa Efek Indonesia Periode 2010 - 2014)". Journal of Business Studies. Vol. 2(1): hal 1-13

Greenidge, Kevin dan Grosvenor, Tiffany. 2010. "Forecasting Non-Performing Loans in Barbados". Business, Finance \& Economics in Energing Economies. Vol. 5(1): pp 80-108

Ghozali, Imam. 2016. Aplikasi Analisis Multivariate dengan Program IBM SPSS 21. Semarang: Badan Penerbit Universitas Diponegoro

Haryani, Iswi. 2010. Restrukturisasi dan Penghapusan Kredit Macet. Jakarta: Elex Media Komputindo.

Hasibuan. 2005. Dasar-Dasar Perbankan. Jakarta: Bumi Kasara

Ismail. 2009. Akuntansi Bank Teori dan Aplikasi dalam Rupiah. Jakarta: Kencana Prenada Media Group

Kasmir. 2014. Manajemen Perbankan. Jakarta: Rajawali Pers.

Kuncoro, Mudrajad. 2009. Metode Riset untuk Bisnis dan Ekonomi. Jakarta: Erlangga

Maholtra, Naresh K. 2004. Riset Pemasaran Pendekatan Terapan Edisi 4. New Jersey: Pearson Education.

Makri, Vasiliki., Athanasios Tsagkanos, and Athanasios Bellas. 2014. "Determinants of Non-Performing Loans: The Case of Eurozone". Panoeconomicus. Vol. 2: pp 193-206

Messai, Ahlem Selma dan Jouini, Fathi. 2013. "Micro and Macro Determinants of NonPerforming Loans". International Journal of Economics and Financial Issues. Vol. 3(4): pp 853-860
Muljono, Teguh Pudjo. 1999. Analisa Laporan Keuangan Untuk Perbankan. Jakarta: Djambatan.

Nyor, Terzungwe dan Mejabi, Simon Kolawole. 2013. "Impact of Corporate Governance on Non-Performing Loans of Nigerian Deposit Money Banks". Journal of Business \& Management. Vol. 2(3): pp 12-21

Osei-Assibey, Eric dan Asenso, Joseph kwadwo. 2015. "Regulatory capital and its Effect on Credit Growth, Non-Performing Loans and Bank Efficiency Evidence from Ghana". Journal of Financial Economic Policy. Vol. 7(4): pp 401-420

Riyadi, Slamet. 2006. Banking Assets and Liability Management. Jakarta: Lembaga Penerbit FEUI

Rosita, Maya dan Musdholifah. 2016. "Pengaruh Makroekonomi, Capital Adequacy ratio, Loan To Deposit ratio dan pertumbuhan Kredit Terhadap Non Performing Loan Pada Bank Asing Di Indonesia Periode 2013-2014". Jurnal Ilmu manajemen. Vol. 4(2): hal 437-448

Saba, Irum., Rehana Kouser, and Muhammad Azeem 2012. "Determinants of Non Performing Loans: Case of US Banking Sector". The Romanian Economic Journal. Vol. 15(4): pp 141-152

Sastradipoera, Komarudi. 2004. Strategi Manajemen Bisnis Perbankan. Bandung: Kappa Sigma

Simorangkir, O.P. 2004. Pengantar Lembaga Keuangan Bank dan Non Bank. Bogor: Ghalia Indonesia.

Skarica, Bruna. 2013. "Determinant of Non Performing in Central and Eastern Europian Countries". Financial Theory and Practice. Vol 38 (1): pp 37-59

Sugiyono. 2011. Metode Penelitian Pendidikan Pendekatan Kuantitatif, Kualitatif, dan $R \& D$. Bandung: Alfabeta

Sukirno, Sadono. 2012. Makroekonomi: Teori Pengantar. Jakarta: PT Raja Grafindo Persada

Sukirno, Sadono. 2008. Mikroekonomi: Teori Pengantar Edisi Ketiga. Jakarta: PT Raja Grafindo Persada

Sulhan, M dan Siswanto, Ely. 2008. Manajemen Bank: Konvensional \& Syariah. Malang: UIN-Malang Press. 
Suyatno, Thomas. 2007. Kelembagaan Perbankan. Jakarta: Gramedia Pustaka Utama

Tika, Mohammad Pabundu. 2006. Budaya Organisasi Dan Peningkatan Kinerja Perusahaan. Jakarta: Bumi Aksara

Vatansever, Metin dan Hepsen, Ali. 2013. "Determining Impacts in NonPerforming Loan Ratio in Turkey". Journal of Finance and Invesment Analysis. Vol 2(4): pp 119-129

Waluyo, Dwi Eko. 2006. Teori Ekonomi Makro. Malang: UMM

Washington, Gitonga Kariuki. 2014. "Effects of Macroeconomic Variables on Credit Risk in The Kenyan Banking System". International Journal of Business and Commerce. Vol. 3(9): pp 01-26

Widjanarto. 2003. Hukum dan Ketentuan Perbankan di Indonesia. Jakarta: Pustaka Utama Grafiti 